Endocrinol. Japon. 1983, 30 (6), 715-721

\title{
Renin-Angiotensin System and Plasma Aldosterone in Cushing's Syndrome
}

\author{
Tsuneharu BABA, Kazumi AOYAGI, Shuya MURABAYASHI, \\ Kazuo SASAKI, KazUo NIGAWARA* and Kazuo TAKEBE
}

Third Department of Internal Medicine, *Department of Urology, Hirosaki University School of Medicine, Hirosaki, 036

\begin{abstract}
The renin-angiotensin system was studied in eight patients with Cushing's syndrome (four with adrenal adenoma and four with adrenal hyperplasia) and in five normal controls. Basal plasma renin activity (PRA) and aldosterone concentration (PAC) were similar in supine position among Cushing's syndrome due to adrenal adenoma (PRA ; $1.0 \pm 0.3 \mathrm{ng} / \mathrm{ml} / \mathrm{h}, P A C ; 7.4 \pm 1.0 \mathrm{ng} / \mathrm{dl}$, mean $\pm \mathrm{SE}$ ), those due to adrenal hyperplasia $(1.0 \pm 0.2,6.9 \pm 0.8)$ and the controls $(0.8 \pm 0.1,6.4 \pm 0.4)$. The PRA after furosemide $(1 \mathrm{mg} / \mathrm{kg}$ i.v.) and $120 \mathrm{~min}$. upright posture stimulation was similar among Cushing's syndrome due to adrenal adenoma $(2.2 \pm 0.7 \mathrm{ng} / \mathrm{ml} / \mathrm{h})$, those due to adrenal hyperplasia $(2.6 \pm 1.7)$ and the controls $(2.5 \pm 1.2)$. However, the PAC response after the stimulation in Cushing's syndrome due to adrenal hyperplasia (7.1 $\pm 1.2 \mathrm{ng} / \mathrm{dl})$ was significantly lower than that in the controls $(17.5 \pm 2.1)(\mathrm{p}<0.01)$, although there was no significant difference between the PAC response in Cushing's syndrome due to adrenal adenoma $(12.6 \pm 1.0)$ and the controls. These results indicate that PAC response to furosemide and upright pasture stimulation might be suppressed in Cushing's syndrome due to adrenal hyperplasia.
\end{abstract}

The renin-angiotensin system in Cushing's syndrome has been studied by some researchers (Brown et al., 1965, Schambelan et al., 1971, Krakoff et al., 1973, 1975a). ACTH and glucocorticoid have been reported to increase plasma renin substrate (PRS) (Haynes et al., 1953, Krakoff, 1973) in animals and in man. Increased PRS was reported in Cushing's syndrome (Krakoff et al., 1975b). However, plasma renin activity (PRA) was not always elevated and was usually within the normal range or slightly low (Brown et al., 1965). The production of aldosterone was usually within the normal range (Schambelan et al., 1971). As to the response of the plasma aldosterone concentration (PAC) to furosemide and upright posture stimulation, Kato (1981) reported that PAC increased normally after the stimulation in 2 Cushing's syndrome due to adrenal adenoma. Meanwhile, Mantero et al. (1978) observed reduced excretion of urinary aldosterone after furosemide administration in Cushing's syndrome due to adrenal hyperplasia. The following studies were undertaken to elucidate whether the PAC response was suppressed in Cushing's syndrome due to adrenal adenoma or due to adrenal hyperplasia, when furosemide and upright posture stimulation were added. 


\section{Materials and Methods}

Four patients with Cushing's syndrome (adrenal adenoma), four with Cushing's disease (adrenal hyperplasia) ( 2 males and 6 females, mean age $37 \pm$ 3 SE yr; range 26-54), and five normal controls (2 males and 3 females, mean age $39 \pm 3 \mathrm{SE}$ yr; range 24-58) were studied after their informed consent had been obtained. All the patients in this study had clinical features of hypercortisolism. Renal function was normal in 6 patients and impaired in 2 patients, with a reduced level of creatinine clearance (patients No. $539.5 \mathrm{ml} / \mathrm{min}$ and No. $660.0 \mathrm{ml} / \mathrm{min}$ ) (Table 1). The blood pressure of the patients was $154 \pm 5 / 99 \pm$ $3 \mathrm{mmHg}$ (mean $\pm \mathrm{SE}$ ) on admission. However, after taking constant diet and rest, blood pressure decreased to $139 \pm 5 / 89 \pm 4 \mathrm{mmHg}$ when the examinations were held. The diagnosis of the patients was made on the basis of the presence of hypercortisolism, the absence of a diurnal rhythm of plasma cortisol, and insufficient suppression of urinary excretion of 17-hydroxycorticosteroids (17-OHCS) in response to $2 \mathrm{mg}$ dexamethasone orally for 2 days. Further diagnosis of Cushing's disease was made on the basis of the increased level of plasma ACTH and a decrease in urinary 17-OHCS by at least 50 $\%$ of the basal level in response to $8 \mathrm{mg}$ dexamethasone orally for 2 days. The pituitary area was studied radiologically by CT scans and lateral polytomography of the sella turcica. Before the study the subjects were placed on a constant diet containing $150-170 \mathrm{mEq} /$ day sodium, $60-70 \mathrm{mEq} /$ day potassium, and $2,200 \mathrm{Kcal} /$ day for a week. All tests were performed at $0900 \mathrm{~h}$ after $60 \mathrm{~min}$. of recumbency. Blood was drawn through an indwelling needle in the antecubital vein.

\section{Furosemide and upright posture}

The subjects were kept in a upright position for
$120 \mathrm{~min}$. after i.v. bolus furosemide $(1 \mathrm{mg} / \mathrm{kg})$ was administered. Blood samples were obtained at 0900 and $1100 \mathrm{~h}$ for measurement of PRA and PAC.

\section{Angiotensin II (AII) infusion}

A II (5-Ileu angiotensin II) $(5.0 \mathrm{ng} / \mathrm{kg} / \mathrm{min})$ was continuously infused intravenously for $10 \mathrm{~min}$. using a micro-infusion pump (patient No. 1-6). Blood samples for PAC measurement were collected before and after the infusion.

\section{3. $S Q 14225$ test}

The subjects received $50 \mathrm{mg}$ of SQ 14225 orally (patient No. 1-5) and blood pressure was monitored with an automatic sphygmomanometer (Japan Colin $\mathrm{BP}-203 \mathrm{X}$ ) until $60 \mathrm{~min}$. after the administration of the drug.

PRA (Haber et al., 1969) and PAC (Ogihara et al., 1977) were measured by radioimmunoassay. Serum potassium was determined by the ion-selective electrode method. Plasma angiotensin-converting enzyme (ACE) was determined (patient No. 8) by UV method (Lieverman, 1975). The statistical difference between groups was calculated using Student's $t$-test. Data were presented as mean $\pm \mathrm{SE}$.

\section{Results}

\section{Effects of furosemide and upright posture}

Basal supine PRA values were similar in patients with adrenal adenoma $(1.0 \pm 0.3 \mathrm{ng} /$ $\mathrm{ml} / \mathrm{h})$, those with adrenal hyperplasia $(1.0 \pm$ $0.2 \mathrm{ng} / \mathrm{ml} / \mathrm{h})$ and the controls $(0.8 \pm 0.1 \mathrm{ng} /$ $\mathrm{ml} / \mathrm{h}$ ) (Fig. 1). The PRA after the furosemide and upright posture stimulation was similar in patients with adrenal adenoma

Table 1. Clinical features of subjects

\begin{tabular}{|c|c|c|c|c|c|c|c|c|c|c|}
\hline \multirow{2}{*}{$\begin{array}{c}\text { Patient } \\
\text { No. }\end{array}$} & \multirow[b]{2}{*}{ Sex } & \multirow{2}{*}{$\begin{array}{l}\text { Age } \\
(\mathrm{yr})\end{array}$} & \multirow{2}{*}{$\begin{array}{c}\text { Plasma } \\
\text { cortisol } \\
(\mathrm{ug} / \mathrm{dl})\end{array}$} & \multicolumn{2}{|c|}{$\begin{array}{c}\text { Urinary 17-OHCS } \\
(\mathrm{mg} / \text { day })\end{array}$} & \multirow{2}{*}{$\begin{array}{r}\text { Plasma } \\
\text { ACTH } \\
(\mathrm{pg} / \mathrm{ml})\end{array}$} & \multirow{2}{*}{$\begin{array}{l}\text { Blood** } \\
\text { pressure } \\
(\mathrm{mmHg})\end{array}$} & \multirow{2}{*}{$\begin{array}{c}\text { Serum } \\
\text { potassium } \\
(\mathrm{mEq} / \mathrm{L})\end{array}$} & \multirow{2}{*}{$\begin{array}{l}\text { Kidney } \\
\text { function }\end{array}$} & \multirow[b]{2}{*}{ Lesion } \\
\hline & & & & $\begin{array}{l}\text { Before } \\
\text { dexame- } \\
\text { thasone }\end{array}$ & $\begin{array}{l}\text { After } \\
\text { dexame- } \\
\text { thasone }\end{array}$ & & & & & \\
\hline 1 & $\mathrm{~F}$ & 29 & $20.4 *$ & 26.0 & 22.4 & 10 & $170 / 110$ & 3.7 & normal & rt. adrenal \\
\hline 2 & $\mathrm{~F}$ & 26 & 26.2 & 12.8 & 14.2 & 10 & $150 / 84$ & 3.6 & normal & rt. adrenal \\
\hline 3 & $\mathrm{~F}$ & 30 & 24.7 & 27.8 & 25.4 & 10 & $139 / 93$ & 3.7 & normal & It. adrenal \\
\hline 4 & $\mathrm{~F}$ & 28 & 22.0 & 29.0 & 25.9 & 145 & $171 / 101$ & 3.3 & normal & pituitary \\
\hline 5 & M & 54 & 23.2 & 29.0 & 24.5 & 496 & $158 / 109$ & 3.1 & reduced & pituitary \\
\hline 6 & $F$ & 46 & 22.6 & 15.2 & 12.5 & 202 & $132 / 95$ & 3.8 & reduced & pituitary \\
\hline 7 & $\mathrm{~F}$ & 34 & 14.8 & 11.5 & - & 10 & $160 / 104$ & 4.4 & normal & lt. adrenal \\
\hline 8 & M & 51 & 17.1 & 22.4 & 24.9 & 410 & $158 / 98$ & 3.8 & normal & pituitary \\
\hline
\end{tabular}




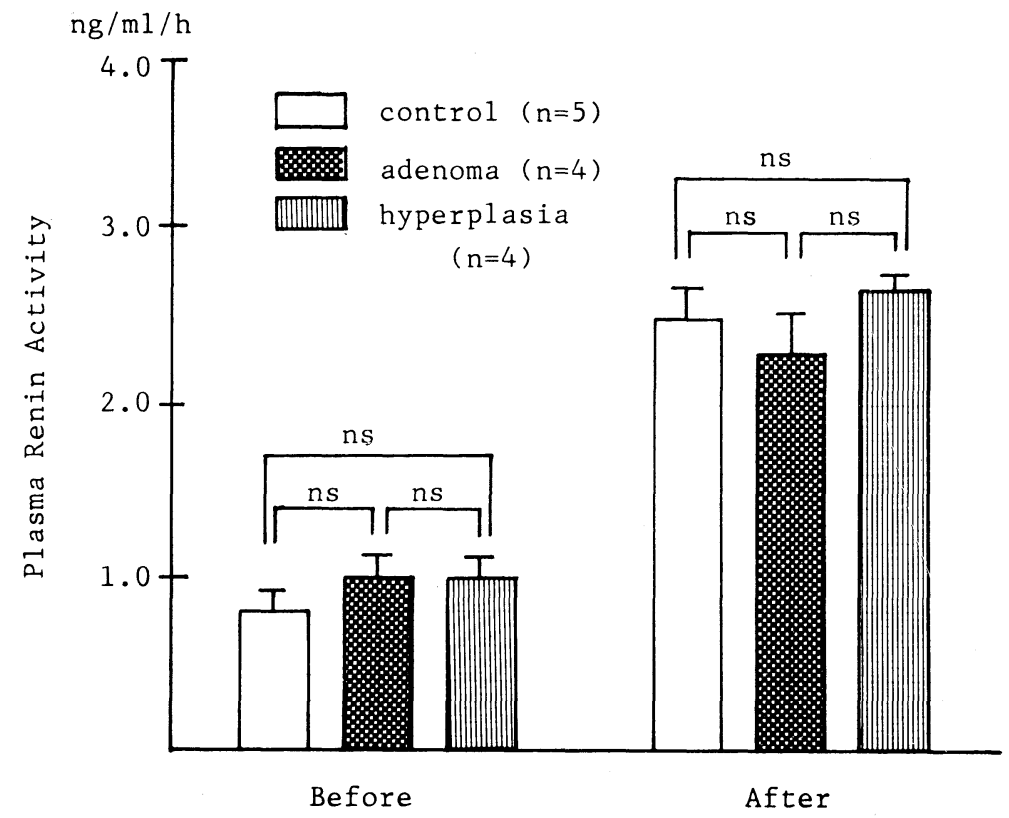

Fig. 1. Plasma renin activity (PRA) before and after furosemide ( $1 \mathrm{mg} / \mathrm{kg}$ i.v. ) and upright posture (120 min.) stimulation in Cushing's syndrome due to adrenal adenoma, adrenal hyperplasia and controls. Data are mean $\pm \mathrm{SE}$.

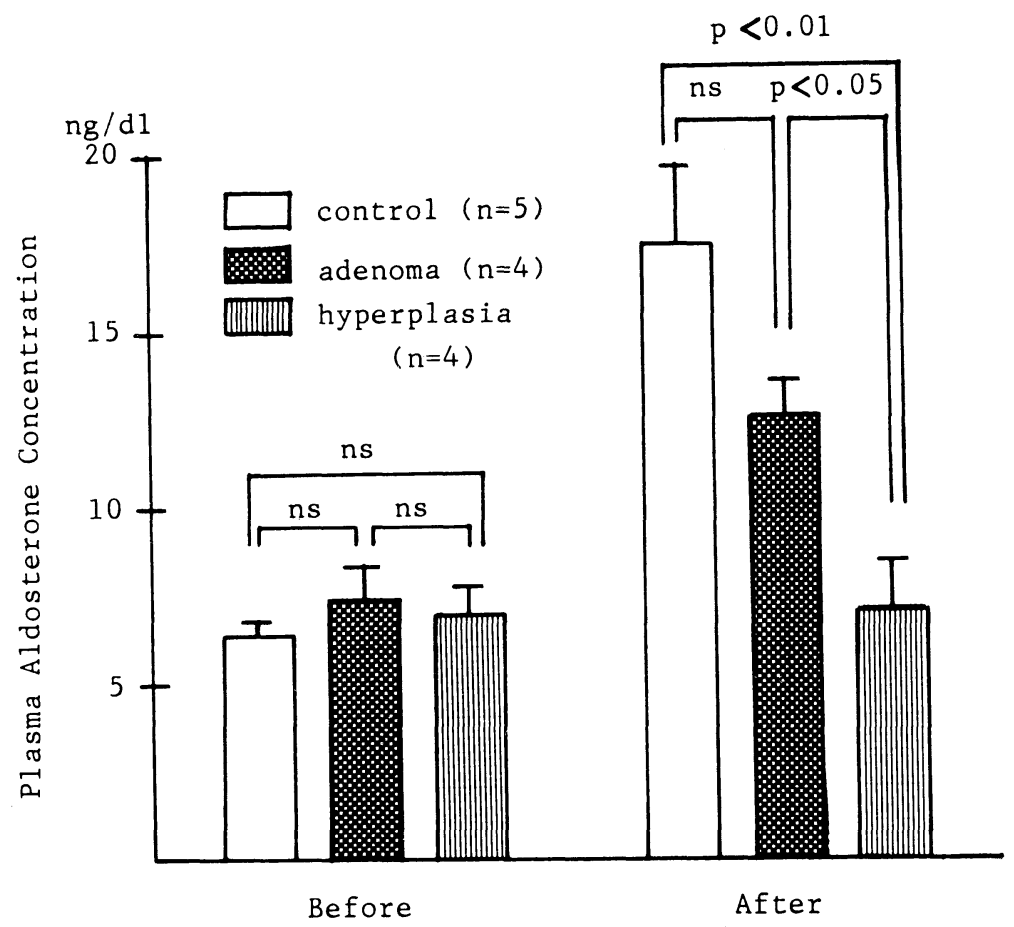

Fig. 2. Plasma aldosterone concentration (PAC) before and after furosemide (1 mg/ $\mathrm{kg}$ i.v.) and upright posture (120 min.) stimulation in Cushing's syndrome due to adrenal adenoma, adrenal hyperplasia and controls. Data are mean \pm SE. 
Fig. 3. Plasma aldosterone concentration (PAC) before and after the infusion of 5Ileu angiotensin II $(5.0 \mathrm{mg} /$ $\mathrm{kg} / \mathrm{min}$ i.v.) in Cushing's syndrome due to adrenal adenoma, adrenal hyperplasia and controls. Data are mean $\pm \mathrm{SE}$.
$(2.2 \pm 0.7 \mathrm{ng} / \mathrm{ml} / \mathrm{h})$, those with adrenal hyperplasia $(2.6 \pm 1.7 \mathrm{ng} / \mathrm{ml} / \mathrm{h})$ and the controls $(2.5 \pm 1.2 \mathrm{ng} / \mathrm{ml} / \mathrm{h})$. Basal supine PAC was similar in patients with adrenal adenoma $(7.4 \pm 1.0 \mathrm{ng} / \mathrm{dl})$, those with adrenal hyperplasia $(6.9 \pm 0.8 \mathrm{ng} / \mathrm{dl})$ and the controls $(6.4$ $\pm 0.4 \mathrm{ng} / \mathrm{dl}$ ) (Fig. 2). However, the PAC after the stimulation was $12.6 \pm 1.0 \mathrm{ng} / \mathrm{dl}$ in patients with adrenal adenoma, $7.1 \pm 1.2 \mathrm{ng} /$ dl in those with adrenal hyperplasia and $17.5 \pm 2.1 \mathrm{ng} / \mathrm{dl}$ in the controls. The PAC in patients with adrenal hyperplasia was significantly lower $(\mathrm{p}<0.01)$ than that in the controls.

\section{Effects of $A$ II infusion}

Basal supine PAC was similar in patients with adrenal adenoma $(5.9 \pm 1.5 \mathrm{ng} / \mathrm{dl})$, in those with adrenal hyperplasia $(4.8 \pm 1.2 \mathrm{ng} /$ dl) and in the controls $(5.8 \pm 1.4 \mathrm{ng} / \mathrm{dl})$. The infusion of A II caused a significant increase in PAC in each group $(\mathrm{p}<0.05)$. The PAC after A II infusin was $13.9 \pm 3.3 \mathrm{ng} / \mathrm{dl}$ in patients with adrenal adenoma, $9.1 \pm 2.3 \mathrm{ng} /$ dl in those with adrenal hyperplasia and $11.9 \pm 1.3 \mathrm{ng} / \mathrm{dl}$ in the controls. There was no significant difference among PAC values after A II infusion (Fig. 3).

\section{SQ 14225 test}

Oral administration of SQ slightly lowered the blood pressure at $60 \mathrm{~min}$. in patients with adrenal adenoma $(123 \pm 4 / 86 \pm 6 \mathrm{mmHg}$ to $111 \pm 4 / 80 \pm 3 \mathrm{mmHg}$ ) and in the controls $(125 \pm 5 / 82 \pm 4 \mathrm{mmHg}$ to $118 \pm 8 / 75 \pm 4 \mathrm{~mm}-$ $\mathrm{Hg}$ ). However, the blood pressure in patients with adrenal hyperplasia was hardly decreased $(140 \pm 6 / 96 \pm 9 \mathrm{mmHg}$ to $138 \pm 5 / 97$ $\pm 8 \mathrm{mmHg}$ ) (Fig. 4). The decrease in blood pressure $(\triangle \mathrm{BP})$ was not significantly difference between patients with adrenal adenoma $(12 \pm 1 / 6 \pm 3 \mathrm{mmHg})$ and the controls $(7 \pm 8 /$ $7 \pm 4 \mathrm{mmHg}$ ).

Plasma ACE activity in patient No. 8 with adrenal hyperplasia was $12.6 \mathrm{U} / \mathrm{ml}$ (normal range $18-43 \mathrm{U} / \mathrm{ml}$ ). 


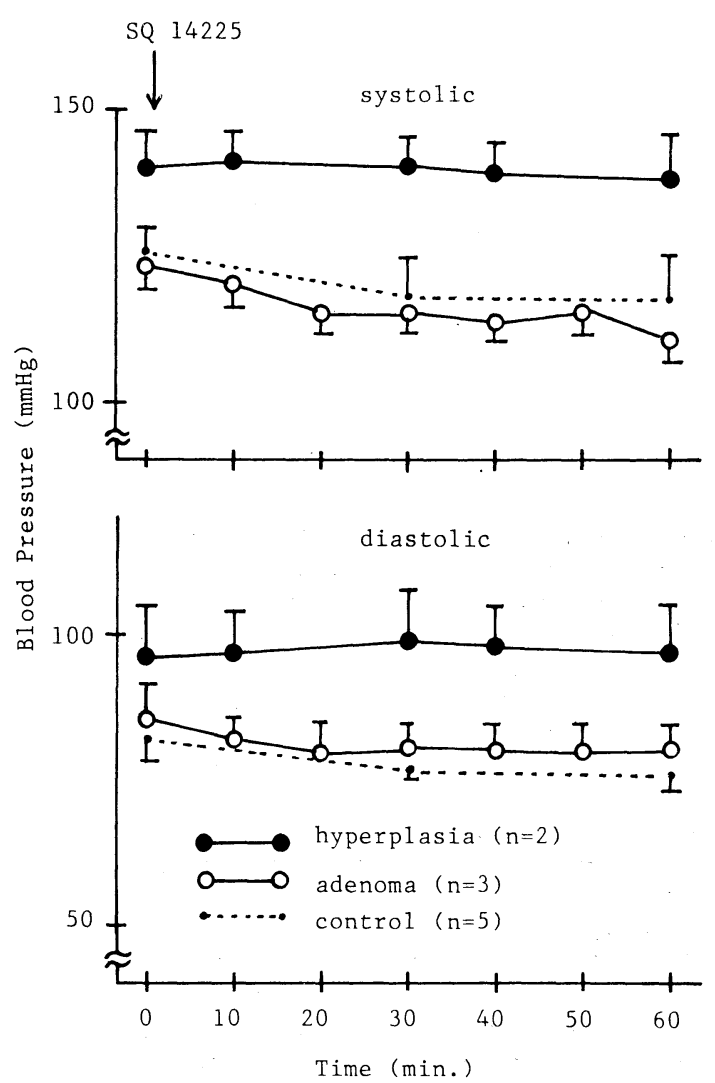

Fig. 4. Blood pressure responses to SQ 14225 (50 mg p.o.) in Cushing's syndrome due to adrenal adenoma, adrenal hyperplasia and controls. Data are mean $\pm S E$.

\section{Discussion}

The basal supine PRA values and PAC were similar in patients with Cushing's syndrome and the controls. The PRA response to furosemide and upright posture stimulation was similar among three groups. However, it is of particular interest that PAC response in the patients with adrenal hyperplasia to the stimulation was significantly smaller than that in normal controls. Mantero et al. (1978) reported a similar phenomenon: urinary aldosterone excretion did not increase after furosemide administration in 3 of 5 cases of Cushing's syndrome due to adrenal hyperplasia, and they thought that responsiveness of aldosterone to the usual stimuli, such as orthostatism and furosemide, might be partially suppressed in Cushing's syndrome due to adrenal hyperplasia. However, Kato (1981) observed that furosemide stimulation provoked normal response in PAC in 2 Cushing's syndrome cases due to adrenal adenoma. In our experiment, PAC response to the stimulation was significantly reduced in patients with adrenal hyperplasia compared to the controls and patients with adrenal adenoma. Our results were similar to Mantero's (1978) and Kato's (1981). Does this account for the difference between adrenal hyperplasia and adenoma ? Generally, secretion of aldosterone is regulated by the renin-angiotensin system (Laragh et al., 1960), changes in potassium (Davis et al., 1963) and sodium homeostasis (Blair et al., 1965), ACTH (McCaa et al., 1971), and partially by dopaminergic suppression (Norviato et al., 1977). Stimulation by furosemide and postural change is considered to be mediated chiefly by the renin-angiotensin system (Michelakis, Horton, 1970, Gordon et al., 1967). Some inhibitory mechanism or impairment in the renin-angiotensin system was implicated as a cause of the poor aldosterone response in Cushing's syndrome due to adrenal hyperplasia in our experiment. Mantero et al. (1978) observed that low response in urinary aldosterone was improved after dexamethasone administration in 2 of 3 Cushing's syndrome cases due to adrenal hyperplasia. The observation suggests that ACTH might modulate the aldosterone response to furosemide and upright posture stimulation. Acute administration of ACTH is known to increase both cortisol and aldosterone (Ulick, 1976).. However, chronic exogenous administration of ACTH produces no sustained elevation in aldosterone or even suppresses aldosterone level to subnormal (Rauh et al., 1979, FuchsHammoser et al., 1980). Therefore, the poor 
aldosterone response in Cushing's syndrome due to adrenal hyperplasia might be explained by the inhibitory effect of $\mathrm{ACTH}$, which was secreted excessively for a long period, on aldosterone secretion.

Our observation of the effects of A II infusion, which was undertaken to evaluate the adrenal reactivity to exogenous A II, was somewhat contrary to the speculation above, since the PAC response in the patients with adrenal hyperplasia was similar to that in the controls. From the results the angiotensin II -aldosterone pathway appears to be normal in patients with adrenal hyperplasia. However, it is also possible that the amount of A II infused in our experiment was too large to evaluate the small difference in adrenal reactivity, and the large dose might be the cause of the similar response in PAC in patients with hyperplasia and the controls.

Blood pressure response to ACE inhibitor was studied to evaluate a role of the reninangiotensin system in Cushing's syndrome. In 2 Cushing's syndrome due to adrenal hyperplasia, a reduced hypotensive effect was observed compared to the controls. Meanwhile, the hypotensive effect was similar in Cushing's syndrome due to adrenal adenoma and the controls. The reduced hypotensive effect of ACE inhibitor may implicate decreased ACE activity in subjects with adrenal hyperplasia. And patient No. 8 showed a low level of ACE activity. However, we haven't measured plasma A II levels in the subjects, and further studies are needed before any conclusion can be drawn.

Other factors, such as the presence of hypopotassemia, increased total blood volume (Agrest et al., 1974), and possibly increased total exchangeable sodium might have modulated the aldosterone response to the stimulation. However, there would be hardly any difference in these factors between Cushing's syndrome due to adrenal hyperplasia and those due to adrenal adenoma. Our data may suggest that the response in PAC to furosemide and upright posture stimulation is suppressed in patients with Cushing's syndrome due to adrenal hyperplasia compared with the normal control, and that the cause of the suppressed phenomenon might be an inhibitory effect of ACTH, which was released excessively for a long time, on aldosterone secretion. Further studies will be needed in order to investigate this.

\section{References}

Agrest, A., S. Finkelman and F. Elijovich (1974). Hemodinamica de la hipertension arterial en el Sindrome de Cushing. Medicina (Buenos Aires) 34, 457.

Blair, W. J. R., F. P. Coghlan, D. A. Denton, J. R. Goding, M. Wintour and R. D. Wright (1965). Effect of variations of plasma sodium concentration on the adrenal response to angiotensin II. Circ. Res. 17, 386-393.

Brown, J. J., D. L. Davies, A. F. Lever and J. I. S. Rovertson (1965). Plasma renin concentration in human hypertension, II : renin in relation to aetiology. Br. Med. J. 2, 1215-1219.

Davis, J. O., J. Uroquhart, J. T. Higgisn, A. Casper and E. Cavanaugh (1963). Effects of alteration of plasma sodium and potassium concentration in aldosterone secretion. J. Clin. Invest. 42, 597-609.

Fuchs-Hammoser, R., M. Schweiger and W. Oelkers (1980). The effect of chronic low-dose infusion of ACTH (1-24) on renin, renin-substrate, aldosterone and other corticosteroids in sodium replete and deplete man. Acta Endocrinologica 95, 198206.

Gordon, R. D., O. Kuchel, G. W. Liddle and D. P. Island (1967). Role of the sympathetic nervous system in regulating renin and aldosterone production in man. J. Clin. Invest. 46, 599-605.

Haber, E., T. Koerner, L. B. Page, B. Kliman and A. Purnode (1969). Application of a radioimmunoassay for angiotensin I to the physiologic measurements of plasma renin activity in normal human subjects. J. Clin. Endocrinol. Metab. 29, 1349-1355.

Haynes, F. W., P. H. Forsham and D. M. Hume (1953). Effects of ACTH, cortisone, deoxycorticosterone and epinephrine on plasma hypertensinogen and renin concentration of dogs. Am. J. Physiol. 172, 265-275.

Kato, K. (1981). Studies on the pathogenesis of hypertension in Cushing's syndrome: relationship of renin-angiotensin-aldosterone system to vascular response. Annual Report of the Ministry of Health and Welfare "Disorders of steroid hormones" Research Committee 1980, Japan. 208- 
217.

Krakoff, L. R. (1973). Measurement of plasma renin substrate by radioimmunoassay of angiotensin $\mathrm{I}$ : concentration in syndromes associated with steroid excess. J. Clin. Endocrinol. Metab. 37, 110-117.

Krakoff, L. R., F. Nicolis and B. Amsel (1975a). Pathogenesis of hypertension in Cushing's syndrome. Am. J. Med. 58, 218-220.

Krakoff, L. R., R. Selvadurai and E.Sutter (1975b). Effect of methylprednisolon upon arterial pressure and the renin angiotensin system in the rat. $\mathrm{Am}$. J. Physiol. 226, 613-617.

Laragh, J. H., M. Angers, W. G. Kelly and S. Lieberman (1960). Hypotensive agents and pressor substances. J. A. M. A. 174, 234-240.

Lieberman, J. (1975). Elevation of serum angiotensinconverting enzyme (ACE) level in sarcoidosis. $\mathrm{Am}$. J. Med. 59, 365-372.

Mantero, F., D. Armanini and M. Boscaro (1978). Plasma renin activity and urinary aldosterone in Cushing's syndrome. Horm. Metab. Res. 10, 6571.

McCaa, R.E., V.H. Read, R.D. Bower, C.S. McCaa and A.C. Guyton (1971). Adrenal cortical response to hemodialysis, ACTH and angiotensin II in anephric man. Circulation. 44 (Suppl II), 67.
Michelakis, A. M. and R. Horton (1970). The relationship between plasma renin and aldosterone in normal man. Circ. Res. 26, 27 (Suppl I), 185194.

Norbiato, G., M. Beveilacqua, U. Raggi, P. Micossi and C. Moroni (1977). Metoclopramide increases plasma aldosterone concentration in man. J. Clin. Endocrinol. Metab. 45, 1313-1316.

Ogihara, T., K. Iinuma, K. Nishi, Y. Arakawa, A. Takagi, K. Kurata, K. Miyai and Y. Kumahara (1977). A non-chromatographic non-extraction radioimmunoassay for serum aldosterone. J. Clin. Endocrinol. Metab. 45, 726-731.

Rauh, W., L. S. Levine, K. Gottesdiener, D. Chow, S. E. Oberfield, P. Gunczler, J. Pareira and M. I. New (1979). Adrenocortical function, electrolyte metabolism, and blood pressure during prolonged adrenocorticotropin infusion in juvenile hypertension. J. Clin. Endocrinol. Metab. 49, 52-57.

Schambelan, M., P. E. Slaton and E. G. Biglieri (1971). Mineralcorticoid production in hyperadrenocorticism. Am. J. Med. 51, 299-303.

Ulick, S. (1976). Diagnosis and nomenclature of the disorders of the terminal portion of the aldosterone biosynthetic pathway. J. Clin. Endocrinol. Metab. 43, 92-96. 